\title{
Regional human rights institutions struggling against populism: The case of Venezuela
}

\author{
Gonzalo Candia*
}

(Received 17 December 2018; accepted 20 January 2019)

\begin{abstract}
Latin American history is full of populist experiments. The result of this history is a political culture across the continent characterized by conflict and polarization. The most recent wave of Latin American populism is represented by neo-populism. Neo-populism identifies itself as the "socialism of the $21^{\text {st }}$ century." Its most representative expression is the Chavista regime, which was led first by Hugo Chávez, and then by Nicolás Maduro. This Article, after examining what populism is, considers how regional human rights institutions of the Americas have dealt with the Chavista regime. In doing so, this Article describes the efforts deployed by both the Inter-American Commission and the Inter-American Court of Human Rights to keep Chávez under control. This Article concludes that regional human rights supervision, being relevant in the context of the Venezuelan experience, was finally incapable of either preventing or stopping the authoritarian path adopted by Chávez. This was because: (a) early supervision over the Chavista regime did not avert its leaders from abusing human rights afterwards; and (b) intensifying regional supervision over the regime became paradoxically self-defeating after it took full control of the State apparatus.
\end{abstract}

Keywords: Latin America; neo-populisms; Chavismo; Inter-American Court of Human Rights (IACtHR); Inter-American Commission on Human Rights

\section{A. Introduction}

It is usually assumed that populist regimes create a set of conditions under which human rights of minorities are likely to be harassed. Because of this circumstance, international human rights law empowers regional institutions to supervise populist regimes in this regard. This Article will address how Latin American regional institutions have dealt with this task in the context of the Chavista regime. To do so, this work will study the efforts deployed by both the Inter-American Commission on Human Rights (hereinafter, IACHR or "the Commission") and the Inter-American Court of Human Rights (hereinafter, IACtHR or "the Court") to either prevent or stop human rights abuses committed by the regime of Hugo Chávez in Venezuela between 1999 and 2013. The Venezuelan experience demonstrates that-due to several factors-regional human rights institutions are not always successful when dealing with the evils of populism.

Early regional supervision of Chávez, who assumed power by democratic means in 1999, was unable to deter him from initiating his authoritarian path. This was due to institutional constraints that encouraged regional institutions to defer to the new populist authorities of Venezuela.

\footnotetext{
${ }^{\star}$ Gonzalo Candia is a professor of Constitutional Law and International Human Rights Law, Pontificia Universidad Católica de Chile. Master in Law (LL.M) and Doctor in Law (S.J.D) by Georgetown University. The author would like to thank professors Francisco Urbina and Natalia Torrejón for their useful and insightful comments on this Article, as well as the German Law Journal peer reviewers. Email: gfcandia@fulbrightmail.org. re-use, distribution, and reproduction in any medium, provided the original work is properly cited.
} 
According to classic rules of international law, supranational supervision over states depends on their own consent to be supervised by foreign organizations. If states withdraw that consent, regional supervision ends. In this scenario, regional human rights institutions are likely to supervise populist authorities very cautiously after they have been elected in order to prevent the new populist authorities from withdrawing state consent to supervision. A deferential attitude gives populist leaders time to consolidate their rule within the country. This explains why both the IACHR and the IACtHR adopted a deferential approach to Chávez during the first years of his administration. By doing so, they sought to avoid the prospect of Venezuela exiting the system. In turn, this deferential approach made it easier for Chávez to consolidate his rule between 1999 and 2002.

Regional human rights supervision over the Chavista regime also became self-defeating. After the 2002 coup d'état against Hugo Chávez failed, regional supervision became stricter. This moved Chávez to begin a campaign against the IACHR and the IACtHR. This movement galvanized his followers behind him, which allowed Chávez to exhibit a powerful unity to both the international community and domestic opposition within Venezuela. In this case, when both the IACHR and the IACtHR intensified supervision, they contributed to increasing-rather than reducing-the authority of Chávez because of the internal features of populism itself. This is likely to happen when regional institutions, after realizing the abusive policies embraced by the populist regime, intensify supervision over it. In this context, populist leaders will probably react against regional institutions by confronting them. In turn, this confrontation is likely to reinforce the rule of populist authorities, as the typical dynamics of friend and foe that characterize populist regimes are likely to unite the supporters of the regime under a single leadership against a common enemy. This mobilization of political energy makes the position of the populist leader stronger within the country. This was precisely what transpired in Venezuela after 2003.

In the first Section of this Article, I will briefly describe populism and its problematic characteristics. The second Section will be devoted to addressing the Latin American experience of regional supervision when dealing with those problems derived from populism, particularly considering the case of Venezuela. Finally, the third Section will explain why the results of regional supervision in the Americas differ from those expected by both the IACHR and the IACtHR.

\section{B. Populism: its meaning and features}

\section{Populism in general}

In general terms, populism has been described as: "An ideology which pits a virtuous and homogeneous people against a set of elites and dangerous others who are together depicted as depriving (or attempting to deprive) the sovereign people of their rights, values, prosperity, identity and voice."

For other authors, populism-more than an ideology - is a sort of political malaise of democracy, which develops in certain contexts. ${ }^{2}$ In contrast, there are authors for whom populism represents the very essence of politics and a healthy reaction against the excesses of liberal democracy. ${ }^{3}$ For those authors, populism mobilizes political action, enabling the people to stay at the center of any system of government. ${ }^{4}$ Other literature prefers to avoid offering a substantial definition of populism by arguing that populism is a form of thin ideology that equally serves

\footnotetext{
${ }^{1}$ Daniele Albertazzi \& Duncan McDonnell, Introduction: The Sceptre and the Spectre, in TwenTy-First Century PopUlism 3 (Daniele Albertazzi \&amp; Duncan McDonnell eds., 2008).

${ }^{2}$ See id. at 2.

${ }^{3}$ See Ernesto laclau, On Populist Reason 232 (2015).

${ }^{4}$ See id.
} 
rightist or leftist ideologies. ${ }^{5}$ In this respect, populism would be "a modality of social expression of popular sovereignty, which acquires different forms."6

Despite the many differences regarding the notion of populism, most of the specialized literature coincides in its core elements. Basically, these elements are: (a) The recognition of the people as the supreme political power; (b) the development of a Manichean discourse that radically distinguishes between the people and corrupted elites in power; (c) the immediate appeal to the people's authority that is usually disguised by the mechanisms of political representation; and (d) the need to permanently struggle against an enemy who deprives the people of their rights, culture, or prosperity. ${ }^{7}$

Because of these features, populism represents a serious risk to any polity. In effect, when populism takes hold, it profoundly harms the common good by destabilizing the constitutional order of the nation. This is because truly successful populism requires permanent political struggle. It is this omnipresent and radical conflict that fuels populism. Stated more precisely, the presence of conflict permits populist forces to distinguish between ourselves and the others. ${ }^{8}$ Populist leaders and politicians present the others as minorities who threaten the life, culture, or well-being of political majorities. Using this narrative, the populist politicians aim to convince the majorities about the need to defeat the others in all respects and at any price. ${ }^{9}$ For some populists, minorities can be the elites who enjoy a series of privileges at the cost of exploiting majorities. For other populists, minorities will be those who are simply different-e.g., migrants. This friend and foe logic applied in the context of a radical majority rule creates conditions for majorities that allow them to abuse their political power by depriving minorities of their rights. In effect, in such a context, minorities are always potentially at the disposal of populist majorities.

\section{Populism in Latin America: peronism and neo-populisms}

Historically, Latin America has been a fertile soil for populism. During the 20th century, two forms of populism took hold on the continent: The Peronist-type of populism and the neo-populist movements.

Latin American populism found its most representative expression in the regime of Colonel Juan Perón. He was a very popular figure of Latin American politics before being elected as President of Argentina in 1946. Indeed, he was the secretary of state for labor affairs of the military government that assumed power after the 1943 coup d'état directed against President Ramón Castillo, a civilian conservative. From his position, Perón won a lot of popular support, making his 1946 election possible. After beginning his presidency, Perón, having become the hero of descamisados and trade unions with his wife Evita, implemented a welfare state. Perón rapidly created his own party - the Justicialista party - through which he controlled different organizations of civil society. In 1955, nine years after the 1946 election, Perón was overthrown by a coup d'état led by officials of the armed forces who were unhappy with the progressively fascistic characteristics of the regime. After being exiled to Madrid, from where he strongly influenced Argentinian politics for almost twenty years, Perón returned to Argentina in 1973 to assume the power until his death in 1974. Perón was a sort of example for other populist leaders of Latin America. Indeed, he created the image of Latin American populism during the twentieth century. ${ }^{10}$

In this image, the populist leader was always a strong leader with innate abilities to mobilize masses around him. Because of these abilities, it was assumed that the populist leader had a direct

\footnotetext{
${ }^{5}$ See Cas Mudde \& Cristóbal R. Kaltwasser, Populism: A Very Short Introduction 19 (2017).

${ }^{6}$ Manuel Anselmi, Populism: An Introduction 2 (2017).

${ }^{7}$ See, e.g., Mudde \& Kaltwasser, supra note 5, at 9-19; Albertazzi \& McDonnell, supra note 1, at 4-7.

${ }^{8}$ See Alfio Mastropaolo, Politics against Democracy: Party Withdrawal and Populist Breakthrough, in TwENTY-FIRST Century Populism, supra note 1 , at 34 .

${ }^{9}$ See id. at 12; Albertazzi \& McDonnell, supra note 1, at 5.

${ }^{10}$ See Anselmi, supra note 6, at 55.
} 
connection with the people, and he did not need intermediaries to know and understand the needs of the population. In this regard, this version of the populist leader was also a sort of messiah, whose main duty was to redeem the nation from all their political and social problems. ${ }^{11}$ This special connection with the people also explained the nationalistic character of the populist form of leadership, which went beyond the traditional classifications between right and left.

This traditional twentieth century populist leader in Latin America assumed that his mission was to struggle against corrupted elites-oligarquía-without giving a quarter to them. This image of populist government viewed compromise with the elites as impossible, because they represented only their own selfish interest and not those of the people as a whole. ${ }^{12}$ From an institutional perspective, the populist leader usually despised traditional forms of representative democracy, precisely because they gave voice to those elites who would capture the political process against the will of the people. This is why twentieth century populisms in Latin America usually favored a presidential system with continuing reelection, even at the cost of reforming or changing the current Constitution through unconstitutional means. ${ }^{13}$ In this respect, Latin American populism during the twentieth century was strongly tied to military supported dictatorships. Finally, the traditional Latin American populist leader implemented socialist economic policies. In effect, populist leaders promoted protectionism and advocated for replacing imports with domestic production as mechanisms to promote economic development. Additionally, the Latin American populist leader of those years was always ready to pursue social justice by deploying an aggressive policy of fiscal expansion, the main purpose of which was to redistribute resources more equitably among the population. ${ }^{14}$

Interestingly, the dynamics involved in those economic policies led to a vicious cycle that condemned Latin American nations to return to populism during the twentieth century. ${ }^{15}$ According to economists Rudiger Dornbusch and Sebastian Edwards, Latin American populist regimes during that century usually failed in the management of the economy because the economic policies they embraced created hyperinflation, capital flight, decreasing wages, and so on. As a consequence, the authors continue, new authorities took over to improve the situation. These new authorities, who came into power by elections or coup d'état, normally adopted a series of orthodox measures to stabilize the economy. ${ }^{16}$

Nonetheless, Dornbusch and Edwards argue that these measures paradoxically created the conditions for populism to re-emerge. In effect, the measures adopted by the new authorities usually contracted the economy and did not immediately produce beneficial effects. The dramatic decrease of wages, loss of social subsidies, and lack of foreign investment created even worse conditions for the people than those seen in the recent past. Civil unrest, strikes, and violence routinely took place as a result. Thus, it became normal for rival forces to overthrow the new authorities. Dornbusch and Edwards observe that these new authorities, under the pressure of the population, regularly adopted policies equivalent to those that had just previously crushed the economy. This new rising of populism permitted the vicious cycle to continue indefinitely. ${ }^{17}$

A new form of populism developed on the continent in the last decades of the twentieth century: Neo-populism. After the end of most military dictatorships in Latin America, democracy returned to most of the countries. People placed tremendous hope in their new governments, believing that democracy and liberal economic policies would improve the lives and citizenship of millions of people living in extreme poverty. Nonetheless, due to several different factors, this

\footnotetext{
${ }^{11}$ See id.

${ }^{12}$ See Mudde \& Kaltwasser, supra note 5, at 28.

${ }^{13}$ See ANSELMI, supra note 6, at 58.

${ }^{14}$ E.g., Rudiger Dornbusch \& Sebastián Edwards, The Macroeconomics of Populism, in The Macroeconomics of Populism in Latin America 7-13 (Rudiger Dornbusch \& Sebastián Edwards eds., 1992).

${ }^{15}$ See id. at 7-8.

${ }^{16}$ See id. at 12 .

${ }^{17}$ See id.
} 
did not happen with the rapidity that people expected. The misbehavior of democratic authorities caused the political situation to further deteriorate. Consequently, people became angry at their own political and economic systems, blaming ordinary politicians and institutions for the situation. In this context, fresh waves of leftist populism returned to power in countries such as Venezuela, Bolivia, Ecuador, Nicaragua, and Argentina.

According to Robert Barr, this latest wave of Latin American populism emerged for three reasons. ${ }^{18}$ First, the absence in those countries of a strong system of political parties that offered support to democracy. This circumstance favored those leaders who presented themselves in opposition to traditional political parties. ${ }^{19}$ Second, the generalized corruption within the state moved people to abhor their ruling class, favoring political outsiders. ${ }^{20}$ Finally, the people's perception that corruption led the political process to outcomes against their own interests, which encouraged the population to replace ordinary politicians by people of their own. ${ }^{21}$ Additionally, Manuel Anselmi points out that the appearance of this new leftist populism is related to the economic crises experienced by Latin American states during the final years of the $1990 \mathrm{~s}^{22}$ In effect, because of these crises, governments throughout the region had to reduce or even cut welfare benefits, which in turn created a series of social issues. ${ }^{23}$ This situation created the perfect set of conditions for leftist populisms to re-emerge under the motto "socialism of the twenty-first century."

The political inclinations of these new forms of populism represented an important difference with twentieth century traditional populism. The earlier wave of Latin American populism had tried to place itself beyond the left-right divide. For example, it adopted an authoritarian, nationalistic, and even conservative discourse concerning social values. Yet, populism simultaneously rejected liberal economic policies, promoting socialist ideas in this regard. Moreover, most of Latin American populist leaders identified themselves at the international level as part of the non-aligned movement. On the contrary, the neo-populisms that emerged in Latin America after the election of Hugo Chávez in 1998 defined themselves as socialist and leftists from the very beginning. ${ }^{24}$ This is the reason why leaders such as Hugo Chávez, Nicolás Maduro, Daniel Ortega, Evo Morales, and Néstor Kirchner all constructed powerful ties with the Castro regime in Cuba after obtaining power.

Another typical feature that defines neo-populisms in Latin America is the way in which they emphasize conflict in political discourse. Neo-populist leaders usually promote social conflict by politicizing all types of issues, including economic ones. Technical and social problems become political problems, which open the channels for new forms of conflict and struggle. In turn, this allows the populist leader to target a new enemy to fight - a situation that is ultimately beneficial to the populist leader. This is because by directing the masses against their new enemies, the leader galvanizes his supporters around him, which shows unity and power to the opposition. In practice, this clearly increases the populist leader's own authority over the country. This strategy of social tension is essential to new Latin American populism, supported by public mass media and virulent rhetoric.

A third characteristic of neo-populisms refers to the relation between the leader and civil society. Neo-populists assume the need to make society more homogenous according to their own requirements. Consequently, diversity and political disagreement in society must be minimized as much as possible. As Hugo Chávez said in the speech that opened the sessions of the Venezuelan constituent assembly in 1999:

\footnotetext{
${ }^{18}$ Robert R. Barr, The Resurgence of Populism in Latin America 58 (2017).

${ }^{19}$ See id. at $65-66$.

${ }^{20} \mathrm{See}$ id. at 66.

${ }^{21}$ See id. at 66-69.

${ }^{22}$ ANSELMI, supra note 6 , at 61 .

${ }^{23}$ See id.

${ }^{24}$ See Mudde \& Kaltwasser, supra note 5, at 31.
} 
The people must look back to its common past glories, but simultaneously, the people... must have a common will that unite everyone today. As Bolívar said, "if we do not incorporate the whole people in a same will, if we do not unite the national spirit in that same will, the Republic will be chaos and anarchy". And, I add, the people [without that level of unity] will become a mere aggregation of human beings who live without being conscious about their past, and even worse, without a common will that allow it to confront adversity. I think that... we have [become] a people again. ${ }^{25}$

Minimization of political disagreement is usually achieved by neo-populist forces through the takeover of autonomous civil society bodies-such as trade unions. After they do so, neopopulism instrumentalizes civil society in favor of the regime. This strategy allows neo-populists to silence civil society and any form of political opposition. It is by using these means that neopopulists force the people to become one body with just one will, as Chávez asserted.

Likewise, new populisms in Latin American usually conceive themselves as re-foundational movements. Most of the populist leaders have radically changed the constitutional regimes under which they were elected. This is done to "put into an end the false democracy of the elites." 26 Generally speaking, populist leaders have done so by resorting to unconstitutional means. In this respect, leaders such as Evo Morales in Bolivia in 2006 and Rafael Correa in Ecuador in 2007 followed the pattern implemented by Hugo Chávez in 1999. This pattern basically consists of calling constituent assemblies immediately after taking power, even if the Constitution in force does not permit this type of action. Once the assembly has formed, populist forces take it over. Then, they enforce rules that unfairly favor populist majorities during the constitution-making process. David Landau has identified this process as a form of "abusive constitutionalism." 27 The final outcome of this procedure is a Constitution that (a) adopts a hyper-presidential system of government, which allows the leader to be reelected many times; (b) incorporates a weak unicameral legislature that is unable to properly check the Executive; (c) includes different mechanisms of direct democracy that limit the capacity of representatives to constrain political majorities in power; (d) entrenches a long list of social rights; and (e) assigns a political role to the armed forces.

Finally, neo-populisms in Latin America were, and still are, strongly connected. Despite their nationalistic rhetoric, they quickly built political alliances in the Americas and outside the region - with China, Iran and Russia, for example. A real symbol of this form of populistic solidarity was the ALBA (Alianza Bolivariana para los Pueblos de Nuestra América). ${ }^{28}$ This regional organization, the charter of which was subscribed in La Habana in 2004, includes several states from the Americas that support the economic policies adopted by neo-populistic regimes. ALBA was originally conceived to be an alternative to ALCA (Área de Libre Comercio de las Américas), ${ }^{29}$ the purpose of which was to configure a free trade area in the continent. In part due to the action of ALBA States, the ALCA project failed in 2005.

\footnotetext{
${ }^{25}$ Ana Cristina Bracho, Discurso del Presidente Hugo Chávez en la Instalación de la Constituyente 1999, DE Eso No HABLA (May 2, 2017), https://anicrisbracho.wordpress.com/2017/05/02/discurso-del-presidente-hugo-chavez-en-la-instalacion-dela-constituyente-1999/.

${ }^{26}$ Hugo Chávez, President, Venezuela, Discurso en la Dexagésima primera Asamblea General de la Organización de Naciones Unidas [Speech at the Sixty-First General Assembly of the United Nations] (Sept. 20, 2006) (transcript https:// www.marxists.org/espanol/chavez/2006/0001.htm).

${ }^{27}$ David Landau, Abusive Constitutionalism, 47 U.C. DAvis L. REV. 189 (2013).

${ }^{28}$ This translates literally to "Bolivarian Alliance for the Peoples of our America."

${ }^{29}$ This translates literally to "Free Trade Area of the Americas."
} 
Similarly, UNASUR (Unión de Naciones Suramericanas) ${ }^{30}$ was created under the leadership of populist leaders of the region in 2008. ${ }^{31}$ This organization was devised by Chávez and his followers as a method of limiting the influence of the OAS on the continent. ${ }^{32}$ Initially, UNASUR was seen as a legitimate regional organization because it included not only states under populist regimes, but also states governed by non-populistic authorities. Yet, UNASUR lacks this legitimacy today because Perú, Colombia, Brazil, Argentina, Chile, and Paraguay decided to suspend their participation in April 2018. Therefore, only Ecuador, Venezuela, Bolivia, Uruguay, Suriname and Guyana still remain part of UNASUR.

In conclusion, Latin America has experienced different expressions of populism through its history. The regional system of human rights protection has taken account of this reality and responded accordingly, as will be illustrated in the next Section of this Article.

\section{Struggling against populism in the Americas: the experience of regional human rights mechanisms of supervision}

This second Section of the Article will analyze how both the IACHR and the IACtHR have dealt with the problems of neo-populist regimes, specifically addressing the case of Venezuela.

\section{The Inter-American system of human rights dealing with neo-populism: the case of Venezuela}

Both the IACHR and the IACtHR have developed a significant effort to deter populist authorities from abusing the human rights of minorities, even if those authorities have been elected with impressive popular support in democratic elections. In this respect, the IACtHR has noted:

The bare existence of a democratic regime does not guarantee, per se, the permanent respect of International Law, including International Law of Human Rights, and which has also been considered by the Inter-American Democratic Charter. The democratic legitimacy of specific facts in a society is limited by the norms of protection of human rights recognized in international treaties, such as the American Convention, in such a form that the existence of one true democratic regime is determined by both its formal and substantial characteristics, and therefore, particularly in cases of serious violations of nonrevocable norms of International Law, the protection of human rights constitutes a impassable limit to the rule of the majority, that is, to the forum of the "possible to be decided" by the majorities in the democratic instance.... 33

Applying this doctrine, both the IACHR and the IACtHR continuously supervised what Hugo Chávez did in Venezuela between 1999 and 2013. For these two institutions, the democratic source of Chávez's power was insufficient to justify many of his actions against human rights.

Hugo Chávez was elected President of Venezuela in 1998. As any populist leader, he presented himself as a sort of new messiah called to save the country from the corruption of oligarchical elites who had ruled only in favor of their own self-interest. During the 1998 presidential campaign, Chávez made an electoral promise to radically change the constitutional regime by calling a

\footnotetext{
${ }^{30}$ This translates literally to "Union of South American Nations."

${ }^{31}$ For more information about UNASUR and the foreign policy developed by Hugo Chávez between 1999 and 2013, see Rita Giacalone, Venezuela en UNASUR: Integración Regional y Discurso Político [Venezuela in UNASUR: Regional Integration and Political Speech], 25(1) DesAfÍOS 129 (2013).

${ }^{32}$ See Veronica Smink, ¿Busca la UNASUR Reemplazar a la OEA? [Venezuela in UNASUR: Regional Integration and Political Speech], BBC NEws, Aug. 27, 2011, https://www.bbc.com/mundo/noticias/2011/08/110826_unasur_consejo_ electoral_vs.

${ }^{33}$ Gelman v. Uruguay, Merits, Reparations, and Costs, Judgment, Inter-Am. Ct. H.R. (ser. C) No. 221, II 239 (Feb. 24, 2011).
} 
constituent assembly. But, he knew that that was unlikely to happen because the 1961 Constitution did not allow itself to be amended or replaced in this manner. In this situation, some of his supporters sought an advisory opinion from the Supreme Court asking whether a popular referendum could be organized to call a constituent assembly. This petition was directed to the Court once Chávez was elected, but before he officially assumed presidential powers.

Despite the fact that changes through a constituent assembly were not permitted by the Constitution, the Supreme Court was conscious of Chávez' intentions, and issued an opinion authorizing the referendum. ${ }^{34}$ The decision was mainly based on the argument that the Venezuelan people were sovereign to decide about radical constitutional change because they represented the constituent power, which could not be limited by any existing positive law. ${ }^{35}$ This decision of the Court allowed Chávez to issue an executive order on February 2, 1999-the same day he assumed presidential powers - calling a popular referendum asking electors whether they wanted to install a constituent assembly to replace the Constitution in force. ${ }^{36}$

In so doing, Chávez was acting outside the boundaries of the 1961 Constitution to create a new constitutional order the nature of which was surely to reinforce his rule vis-à-vis the opposition. In October 1999, the Supreme Court affirmed the power of the constituent assembly to redefine the scope of the legislature's authority. Because Chávez had total control over the assembly, he used the assembly to bypass Congress. ${ }^{37}$

Once the new Constitution was promulgated in 1999, Chávez called elections to reinforce his political power. The campaign was characterized by a political discourse in which Chávez permanently appealed to the will of the people, denounced the antipatriotic actions of minorities, and promoted a virulent logic of friend and foes. He was re-elected with fifty-nine percent of the votes. After frustrating a coup d'état in 2002, Hugo Chávez became the supreme power of the country. Playing this role, el Comandante disregarded political minorities, who were violently prosecuted by his regime until his death in $2013 .^{38}$

\section{Venezuela and the IACHR}

The first significant response of the supervisory bodies of the Inter-American system of human rights protection to Chávez was in 2003, when the Inter-American Commission on Human Rights published a first country report on Venezuela. ${ }^{39}$ The Commission denounced how the regime was undermining the rule of law within the country and how political minorities were subject to prosecution. In this respect, the 2003 country report criticized the Chávez regime because of (a) the presence of death squads composed of supporters of Chávez who were arbitrarily killing members of the political opposition without any further investigation; ${ }^{40}(\mathrm{~b})$ the numerous acts of torture applied by governmental officials against civilians; ${ }^{41}$ (c) the "alarming and generalized increase

\footnotetext{
${ }^{34}$ See La Corte Suprema De Justicia [Supreme Court of Justice] Jan. 19, 1999 (Venez.), reprinted in Magistrado Ponente: Humberto J. La Roche, 5(1) IUS ET PRAXIs 589 (1999), http://www.redalyc.org/pdf/197/19750125.pdf.

${ }^{35} I d$. at 602 .

${ }^{36}$ For a full statement of facts, see Joshua Braver, Hannah Arendt in Venezuela: The Supreme Court Battles Hugo Chávez Over the Creation of the 1999 Constitution, 14(3) INT'L J. CONST. L. 555 (2016).

${ }^{37}$ La Corte Suprema De Justicia [Supreme Court of Justice] Oct. 14, 1999 (Venez.), reprinted in Sentencia de la Corte Suprema de Venezuela sobre Decreto de la Asamblea Constituyente, que Contiene la Regulación del Poder Legislativo, 5(2) IUS ET PRAXIS 459(1999), http://www.redalyc.org/pdf/197/19750217.pdf.

${ }^{38}$ For a more complete account of facts, see Landau, supra note 28, at 203-06 (2013).

${ }^{39} \mathrm{See}$ Report on the Situation of Human Rights in Venezuela, Inter-Am. Comm'n H.R., OEA/Ser.L/V/II.118, doc. 4 rev. 2 (2003), http://www.cidh.org/countryrep/Venezuela2003eng/toc.htm.

${ }^{40}$ See id. II 561.

${ }^{41}$ See id. II 562.
} 
in attacks on the media and journalists"; ${ }^{42}$ and (d) the government's multiple interferences in trade unions affairs. ${ }^{43}$

Six years later, the IACHR issued another country report, "Democracy and Human Rights in Venezuela." ${ }^{4}$ This report denounced the many human rights violations that were occurring:

In the present report, the Commission has identified that political intolerance; the lack of independence of the branches of the State in dealing with the executive; constraints on freedom of expression and the right to protest peaceably; the existence of a climate hostile to the free exercise of dissenting political participation and to monitoring activities on the part of human rights organizations; citizen insecurity; violent acts perpetrated against persons deprived of their liberty, trade union members, women, and farmers; and, above all, the prevailing impunity affecting cases of human rights violations are factors that seriously limit the enjoyment of human rights in Venezuela. With the aim of consolidating the democratic system, the State must increase its efforts to combat these challenges and achieve better and more effective protection of the rights guaranteed in the American Convention on Human Rights. ${ }^{45}$

Chávez received this Commission report harshly, to which he responded: "Go to hell, gentlemen from this ineffable Commission." ${ }^{46}$ Despite the efforts behind the elaboration of this extensive 2009 report, Chávez retained his policies against political minorities. In practice, the only concrete outcome of the 2009 report was the encouragement of Chávez seriously considering denunciating the American Convention on Human Rights. ${ }^{47}$

A third country report on Venezuela was published in 2017. At the time of its publication, however, Chávez had already been dead for four years and Nicolás Maduro, his successor, was in power. The Commission did not change its previous criteria, and criticized in emphatic terms the attacks conducted by Maduro against democracy, rule of law, and human rights in Venezuela:

The Commission finds that, overall, such acts demonstrate disdain for the democratic rule of law and the values inherent therein, such as political plurality, respect for the dignity of the human person, and the principle of legality in the State's actions recognized by its Constitution. Ensuring rights and freedoms in a democratic society requires a legal and institutional order in which the law prevails over the will of the rulers, and in which there are judicial controls on the constitutionality and legality of the exercise of public power. ${ }^{48}$

It is clear that the IACHR took many steps intended to remedy human rights violations under the Chávez regime. Nonetheless, the impact of the country reports from 2003, 2009, and 2017 was very limited. The reports only allowed the international community to confirm something that

\footnotetext{
${ }^{42}$ Id. II 563.

${ }^{43}$ Id. II 568.

${ }^{44}$ Democracy and Human Rights in Venezuela, Inter-Am. Comm'n H.R., OEA/Ser.L/V/II, doc. 54 (2009), http://www.cidh. org/countryrep/Venezuela2009eng/VE09.TOC.eng.htm.

${ }^{45}$ Id. II 1163.

${ }^{46}$ Maye Primera, Chávez, de Nuevo Contra la OEA [Chavez, again against the OAS], EL PAís, May 11, 2009, https://elpais. com/internacional/2009/05/11/actualidad/1241992801_850215.html.

${ }^{47}$ American Convention on Human Rights, Nov. 22, 1969, 1144 U.N.T.S. 144; Letter from Nicolàs Maduro Moros, Minister, Popular Power of Foreign Affairs of the Bolivarian Republic of Venezuela, to José Miguel Insulza, Secretary General, Organization of American States (Sept. 6, 2012), http://www.oas.org/dil/esp/Nota_Republica_Bolivariana_de_Venezuela_ al_SG_OEA.PDF.

${ }^{48}$ Democratic Institutions, the Rule of Law and Human Rights in Venezuela, Inter-Am. Comm'n H.R., OEA/Ser.L/V/II, doc. 209 II 476 (2017), http://www.oas.org/en/iachr/reports/pdfs/Venezuela2018-en.pdf.
} 
was clear and obvious: Chávez and Maduro were dictators who had systematically infringed the human rights of political minorities.

The Commission did no better from a preventive perspective. Indeed, the IACHR was unable to anticipate the populist risk implicit in Chávez's policies before 2003, despite the widespread information available about him in those years. In fact, everyone knew that Colonel Hugo Chávez, along with a group of the military, had attempted to overthrow the democratic government in Venezuela in 1992. Moreover, Chávez's intention to change the constitutional regime by unconstitutional means was very well-known in the whole continent, because he never hid his purpose from the public. ${ }^{49}$ Nonetheless, the Commission first adopted a deferential approach to Chávez and his political project. The Commission never criticized the new administration for calling a referendum outside the basic law in 1999 and convening an unconstitutional assembly. Nor did the Commission criticize the Assembly when it limited the constitutional authority of Congress and the Judiciary later that year. Furthermore, the Commission received Chávez in its headquarters of Washington, D.C., in September 1999. By so doing, Chávez became the first Chief of State in history to visit this regional organization. On that occasion, the Commission neither manifested concerns about the illegitimate constituent process Chávez was conducting, nor expressed concerns about the potential infraction of minority rights in Venezuela. On the contrary, the final press release of the Commission praised the visit of President Chávez and his commitment to human rights. ${ }^{50}$

Additionally, the Commission showed support for Hugo Chávez when the coup d'état failed in 2002. Immediately after Chávez was overthrown by the rebels, the Commission issued a press release criticizing the measures adopted by the new administration:

The Commission is closely monitoring the unfolding of events arising from the removal or resignation of President Hugo Chávez Frías. The Commission deplores the dismissal, by a decree issued by the government that took office on April 12, of the highest officers of the judiciary and of independent officials within the executive branch, and the suspension of the mandate of the members of the legislature. These developments, in the IACHR's opinion, could constitute an interruption of the constitutional order as defined in the Democratic Charter. ${ }^{51}$

In this respect, the Commission concluded by urging Venezuela "to promptly restore the rule of law and the democratic system of government by guaranteeing full observance of human rights and basic freedoms." 52 When the IACHR visited Venezuela in May 2002, Chávez thanked the Commission for its support during the coup d'état. ${ }^{53}$ After finishing this visit, the Commission stated in regard of the new Constitution:

The IACHR valued a large number of innovative provisions [of the new Constitution], such as, among others, according constitutional rank to human rights treaties, obligating the State to investigate and punish crimes against human rights, limiting the use of military justice, and eliminating time limits for prosecuting crimes against human rights. ${ }^{54}$

\footnotetext{
${ }^{49}$ Juan Jesús Aznares, Chávez Promete Imponer un Nuevo Orden Politico en Venezuela [Chávez Promises to Impose a New Political Order in Venezuela], EL PAís, Nov. 11, 1998, https://elpais.com/diario/1998/11/11/internacional/910738808_850215. html.

${ }^{50}$ Press Release No. 26/99, Inter-Am. Comm'n H.R. (Oct. 8, 1999), http://www.cidh.org/Comunicados/English/1999/26-99. htm.

${ }^{51}$ Press Release No. 14/02, Inter-Am. Comm'n H.R. (Apr. 13, 2002), http://www.cidh.org/Comunicados/English/2002/ Press14.02.htm.

${ }^{52} \mathrm{Id}$.

${ }^{53}$ Press Release No. 23/02, Inter-Am. Comm'n H.R. II 2 (May 10, 2002), http://www.cidh.org/Comunicados/English/2002/ Press23.02.htm.

${ }^{54}$ Id. II 5.
} 
Finally, even the 2003 country report on Venezuela made zero allusions to the constituent assembly convoked by Hugo Chávez under unconstitutional means in 1999. When the report analyzed the political background of the recent history of Venezuela, the IACHR only referred to events prior to the 1998 presidential election, and those that immediately preceded the 2002 coup. The report did not consider any events that transpired between 1998 and 2002. In this respect, the diagnosis of the Commission was simply:

Notwithstanding the seriousness of the violence and human rights violations previously described [those of the failed coup directed by Hugo Chávez in 1992], the democratic experience in Venezuela continued uninterrupted until the events of April 12, 2002, when another coup d'état was attempted. ${ }^{55}$

Later, the 2009 report of the Commission contributed to legitimize the 1999 unconstitutional referendum by considering it as a valid expression of popular will. ${ }^{56}$ It is therefore interesting to contrast the Commission's attitude to the constitution-making process led by Chávez in 1999, with its later views of the constituent process called by his successor, Nicolás Maduro, in 2017. Indeed, the Commission strongly criticized the decisions of Maduro's constituent assembly in the following terms:

The Inter-American Commission on Human Rights (IACHR) expresses its deep concern regarding the acts of the recently constituted National Constituent Assembly (ANC) in Venezuela that exceed the powers of a constituent body and usurp the powers of the National Assembly which affects the separation of powers and a representative democracy. It is also worrisome the ANC's discretionary power to dismiss and appoint any authority of the Venezuelan State, including magistrates and prosecutors, and to dictate and/or reform laws, and implement decisions without control of other powers and the necessary guarantees required within a democratic society. ${ }^{57}$

The Commission condemned Maduro's constituent assembly in 2017 for a set of actions that did not fundamentally differ from what Chávez's constituent assembly did in 1999. In this context, it is important to note the differences between the ways the IACHR treated Chávez and Maduro during their first years in power. While the Commission acted benevolently to Chávez in 1999, the IACHR acted much more harshly against Maduro in 2017.

In sum: The Commission was unable to foresee Chávez's plans after his election in 1998. By the time the Commission reacted in 2003, it was too late-Chávez had become stronger than ever after defeating the 2002 coup d'état directed against him.

\section{Venezuela and the IACtHR}

In this broad account of Venezuela, it is also necessary to describe the relevant actions taken by the IACtHR to confront Chávez and Maduro. The Court has done much in this regard-even if its actions have not been as effective as many had expected.

The first decision adopted by the IACtHR during the Chávez era was Caso del Caracazo v. Venezuela $^{58}$ in 2002. In resolving this case, the Court condemned Venezuela for the violence employed by the police and the military to repress street protests in 1989. These protests were

\footnotetext{
${ }^{55}$ Report on the Situation of Human Rights in Venezuela, supra note 40, If 74.

${ }^{56}$ See Democracy and Human Rights in Venezuela, supra note 45, If 31.

${ }^{57}$ Press Release No. 131, Inter-Am. Comm'n H.R. If 1 (Aug. 31, 2017), http://www.oas.org/en/iachr/media_center/ PReleases/2017/131.asp.

${ }^{58}$ Caso del Caracazo v. Venezuela, Merits, Reparations, and Costs, Judgment, Inter-Am. Ct. H.R. (ser. C) No. 95, (Aug. 29, 2002).
} 
conducted against the orthodox austerity measures that Carlos A. Pérez's government adopted to stabilize the economy of the country. The event was known as Caracazo. As a consequence of the repression, forty-four protesters died on the streets of Caracas. Some relatives of the victims presented a petition against Venezuela to the IACHR in 1995. Later, the Commission moved this case to the Court in June 1999, just a few months after Chávez became President.

According to Chávez, "Caracazo was the spark that ignited the Bolivarian revolution,"59 and "the result of neoliberal policies." ${ }^{0}$ Because of that, Chávez decided that the State must accept full international responsibility for all deaths that occurred during the Caracazo. This decision was notified to the IACtHR in November 1999, and then confirmed in November $2001 .^{61}$ This position of the State would later make it possible for the IACtHR to condemn Venezuela in August 2002.

Chávez warmly welcomed the IACtHR decision on Caracazo. He essentially saw this judgment as an opportunity to win an advantage over the political opposition by blaming those who were in power when the events of Caracazo took place in 1989. Therefore, he quickly accepted the decision, promising to enforce it. ${ }^{62}$ Even more, Chávez manifested his intention to compensate all victims of Caracazo - not only the individuals defined as victims by the IACtHR decision. ${ }^{63}$ During the 1998 presidential campaign, Chávez made an electoral promise to radically change the constitutional regime by calling a constituent assembly.

Yet, this attitude of the regime quickly changed. A former Venezuelan judge of the IACtHR, Asdrúbal Aguiar, observed that Chávez's support for the system ended when the Court ceased condemnation of Venezuela for events that transpired during previous administrations, and began condemning it for events that occurred after $1999 .{ }^{64}$

The first decision issued by the Court against the Chávez regime dated from 2005. In Caso Blanco Romero and others $v$. Venezuela, ${ }^{65}$ the IACtHR condemned the Venezuelan State for the forced disappearance of a group of civilians in the hands of military members in December 1999. Then, the Court condemned the State in Caso Apitz Barbera and others v. Venezuela in 2008, holding that the removal of five judges of the Supreme Court by judicial authorities in 2003 failed to respect the requirements of due process. During 2009, the IACtHR decided two critical cases concerning free speech rights: Ríos and others $v$. Venezuela ${ }^{66}$ and Perozo and others $v$. Venezuela. ${ }^{67}$ In both cases, the Court condemned the government for persecuting and assaulting journalists in 2002, and again in 2001 and 2005, respectively. A similar approach was adopted by the Court in Caso Granier y otros (Radio Caracas Televisión) v. Venezuela in 2015. In this case, the IACtHR manifested that the governmental decision to close a private TV station in 2007 was adopted

\footnotetext{
${ }^{59}$ Héctor Escalante, Presidente Chávez: el Caracazo fue la Chispa que Encendió el Motor de la Revolución Bolivariana [President Chávez: The Caracazo was the Spark That Ignited the Motor of the Bolivarian Revolution], EL CORREO DEL ORINOCO, Feb. 27, 2010, http://www.correodelorinoco.gob.ve/presidente-chavez-el-caracazo-fue-chispa-que-encendiomotor-revolucion-bolivariana/.

${ }^{60} \mathrm{Id}$.

${ }^{61}$ See Caracazo, No. 95 at II 51.

${ }^{62}$ Gobierno de Venezuela Indemnizó a 600 Víctimas de El Caracazo [Government of Venezuela Compensated 600 Victims of El Caracazo], Telesur, Feb. 27, 2016, https:/www.telesurtv.net/news/Gobierno-de-Venezuela-indemnizo-a-600-victimas-deEl-Caracazo-20160227-0028.html.

${ }^{63} I d$.

${ }^{64}$ See Abraham Zamorano, Venezuela Abandona la Corte Interamericana: ¿Cambia Algo? [Venezuela Abandons the Inter-American Court Does Something Change?], BBC, Sept. 11, 2013, https://www.bbc.com/mundo/noticias/2013/09/ 130909_venezuela_corte_interamericana_salida_derechos_humanos_az.

${ }^{65}$ Caso Blanco Romero and Others v. Venezuela, Merits, Reparations, and Costs, Judgment, Inter-Am. Ct. H.R. (ser. C) No. 138, (Nov. 28, 2005).

${ }^{66}$ Ríos and Others v. Venezuela, Preliminary Objections, Merits, Reparations, and Costs, Judgment, Inter-Am. Ct. H.R. (ser. C) No. 194, (Jan. 28, 2009).

${ }^{67}$ Perozo and Others v. Venezuela, Preliminary Objections, Merits, Reparations, and Costs, Judgment, Inter-Am. Ct. H.R. (ser. C) No. 195, (Jan. 28, 2009).
} 
exclusively on the grounds of the criticism that the station had constantly directed against the Chávez regime.

The Court continued in its condemnation of Venezuela when resolving cases about unjust dismissal of judges ${ }^{68}$ illegal detention of members of the opposition, ${ }^{69}$ infractions of due process rights, ${ }^{70}$ violations of political rights, ${ }^{71}$ extrajudicial killings and police abuses against members of the opposition, ${ }^{72}$ degrading treatment given to political prisoners in jail, ${ }^{73}$ and violation of labor rights. ${ }^{74}$ Because of these series of judgments, Chávez finally denounced the jurisdiction of the Court in 2012. Therefore, the only cases that the IACtHR has decided regarding Venezuela since then are those that were lodged before 2012 .

The IACtHR has developed a series of efforts to deter the Chavista regime from abusing human rights since 2005. Nonetheless, these efforts did not bear fruits for two reasons. First, decisions of the IACtHR against Chávez were not enforced in Venezuela. In fact, the Supreme Court of Venezuela, an institution already under the control of the Executive, decided in 2011 not to enforce decisions from the IACtHR, arguing that some of its judgments were unconstitutional. ${ }^{75}$ Second, the impact of the Court's decisions was limited by the slowness of judicial procedures. The first decision made by the Court against the Chavista regime was issued six years after the violations of rights took place. In this context, and due to this delay, decisions made by the IACtHR did not produce the level of political impact expected by victims who looked to the InterAmerican system for redress.

In sum, decisions made by the IACtHR against Venezuela only confirmed what had already been clear since 2003: Chávez's populist regime was involved in multiple human rights violations. Nonetheless, these efforts of the IACtHR were impotent to stop Chávez from infringing minority rights until his death in 2013.

\section{Conclusion}

The IACHR and the IACtHR have permanently struggled against the Venezuelan neo-populist regime since 2003. These efforts have been insufficient in either preventing or stopping human rights abuses committed by Hugo Chávez first and, then, by Nicolás Maduro. The next Section will shed further light on this situation.

\footnotetext{
${ }^{68}$ Reverón Trujillo v. Venezuela, Preliminary Objections, Merits, Reparations, and Costs, Judgment, Inter-Am. Ct. H.R. (ser. C) No. 197, (June 30, 2009); Chocrón Chocrón v. Venezuela, Preliminary Objections, Merits, Reparations, and Costs, Judgment, Inter-Am. Ct. H.R. (ser. C) No. 227, (July 1, 2011).

${ }^{69}$ Barreto Leiva v. Venezuela, Merits, Reparations, and Costs, Judgment, Inter-Am. Ct. H.R. (ser. C) No. 206, (Nov. 17, 2009).

${ }^{70}$ Usón Ramírez v. Venezuela, Preliminary Objections, Merits, Reparations, and Costs, Judgment, Inter-Am. Ct. H.R. (ser. C) No. 207, (Nov. 20, 2009).

${ }^{71}$ López Mendoza v. Venezuela, Merits, Reparations, and Costs, Judgment, Inter-Am. Ct. H.R. (ser. C) No. 233, (Sept. 1, 2011).

${ }^{72}$ Familia Barrios v. Venezuela, Merits, Reparations, and Costs, Judgment, Inter-Am. Ct. H.R. (ser. C) No. 237, (Nov. 24, 2011); Castillo González and Others v. Venezuela, Merits, Judgment, Inter-Am. Ct. H.R. (ser. C) No. 256, (Nov. 27, 2012); Caso Hermanos Landaeta Mejías and Others v. Venezuela, Preliminary Objections, Merits, Reparations, and Costs, Judgment, Inter-Am. Ct. H.R. (ser. C) No. 281, (Aug. 27, 2014).

${ }^{73}$ Díaz Peña v. Venezuela, Preliminary Objections, Merits, Reparations, and Costs, Judgment, Inter-Am. Ct. H.R. (ser. C) No. 244, (June 26, 2012).

${ }^{74}$ Caso San Miguel Sosa and Others v. Venezuela, Merits, Reparations, and Costs, Judgment, Inter-Am. Ct. H.R. (ser. C) No. 348, (Feb. 8, 2018).

${ }^{75}$ Allan R. Brewer-Carías, El Ilegítimo "Control de Constitucionalidad" de las Sentencias de la Corte Interamericana de Derechos Humanos por Parte de la Sala Constitucional del Tribunal Supremo de Justicia de Venezuela: El Caso Leopoldo López v. Venezuela, Septiembre 2011 [The Illegitimate "Control of Constitutionality" of the Judgments of the Inter-American Court of Human Rights by the Constitutional Chamber of the Supreme Court of Justice of Venezuela: The Leopoldo López v. Case Venezuela, September 2011], 10(2) Estudios Constitucionales 575 (2012).
} 


\section{Institutional and political reasons for the Inter-American system's inability to successfully deal with neo-populism in Venezuela}

International human rights advocates have assumed that regional organizations are apt to keep populist regimes under control. Sometimes, this is true. ${ }^{76}$ Yet, the Venezuelan experience demonstrates that this assumption is not always correct. For example, actions taken by both the IACHR and the IACtHR proved unable to prevent and stop human rights abuses conducted by the Chavista regime. This final Section of this Article will advance some explanations of the options adopted by both the IACHR and the IACtHR when dealing with el Comandante Chávez.

\section{Preventing populism: the question of consent, incentives for early supervision, and uncertainty}

Both the IACHR and the IACtHR did not foresee-or, perhaps, they did not want to anticipatewhat was likely to happen in Venezuela after 1999. Because of that, they reacted against Chávez too late. As noted above, the IACHR did not publish its first country report on Venezuela until 2003. Similarly, the first decision of the IACtHR condemning actions conducted by the regime against the opposition was not issued until 2005. Accordingly, both institutions failed to act against Chávez until his position in Venezuela was too strong to be weakened by criticism from abroad.

The overarching question is why both the IACHR and the IACtHR adopted such an approach to Chávez during the period between 1999 and 2002. It is relatively easy for anyone who evaluates this situation to censure what these supervisory bodies did in this regard. Yet, the IACHR and IACtHR do not deserve excessive blame. Indeed, the institutional design of the Inter-American system itself discouraged the Commission and the Court from choosing a more active path to confront Chávez. After Chávez accessed power by democratic means in Venezuela, both the IACHR and the IACtHR were surely faced with considering what to do afterwards. They could have decided to remain inactive. Nonetheless, these institutions made a different choice. Instead, both the IACHR and the IACtHR had to choose the level of scrutiny they would apply to the regime while striking a fair balance between the costs and gains involved in any potential option. Therefore, in deciding on such a level of scrutiny, both the IACHR and the IACtHR probably pondered: (a) The need to deter a populist regime that was likely to abuse minority rights in the future; and (b) the necessity for regional institutions to maximize their own supervisory powers over states. In doing so, they had to bear in mind that the latter consideration depended critically on the consent of the State that would be checked.

This analysis was particularly accurate in the context of the Inter-American system of human rights protection. According to Article 33 of the American Convention on Human Rights, both the IACHR and IACtHR "have competence with respect to matters relating to the fulfillment of the commitments made by the States Parties to ... [the] Convention." Still, these institutions can supervise state compliance only under the agreement of the state parties to the Convention. In this respect, ratification of the Convention by states automatically empowers the IACHR to receive petitions made by individuals against their own states. Yet, Article 62.1 of the treaty requires additional consent from the states for the IACtHR to have jurisdiction over States Parties to the Convention. Therefore, the supervision developed by both the IACHR and the IACtHR depends on the consent of the very same States that are supervised by the two institutions.

\footnotetext{
${ }^{76}$ For example, the irruption of populist forces in Europe has been limited at some point by the action of the bodies that configure the regional system of human rights protection in the continent. An example of this is the case of the colonel's regime in Greece after the coup d'état in 1974. The regime was rapidly isolated and destabilized due, in part, to the actions of institutions such as the Council of Europe. See Victor Fernández, Facing the Greek Junta: The European Community, the Council of Europe and the Rise of Human Rights Politics in Europe, 24 EUR. REv. HIsT. 358, 358 (2017).
} 
The Venezuelan experience suggests that the issue of state consent has the potential to discourage regional human rights bodies from effectively checking populists after they take power. Indeed, both the IACHR and the IACtHR probably reacted timidly when Chávez gained power in order to prevent political costs for the Inter-American system. Withdrawal of state consent might have created a backlash that would eventually threaten the very existence of this regional arrangement. A domino effect of other states could have also endangered the existence of the system as a whole. Certainly, this was a cost that both the IACHR and the IACtHR were unlikely to accept.

Another factor probably considered by the regional human rights institutions of the Americas when deciding what approach to adopt to Chávez was the perception of states about the legitimacy and utility of the system. ${ }^{77}$ When a system is not seen as completely legitimate by the states-or states perceive that the system renders benefits that are not relevant to them-it is more likely for regional institutions to adopt a more deferential approach to populist authorities during the first years of their regime. This to prevent an exit whose cost for the state might be lower considering the overall context. In contrast, a different attitude is likely to be assumed by regional organizations that belong to systems whose legitimacy is beyond doubt, or to systems that are overall profitable for states. In this scenario, regional institutions may conclude that the exit cost for the new populist authorities is so high that they will surely accept the costs represented by stricter supervision from abroad.

Finally, it is reasonable to assume that both the IACHR and the IACtHR, when pondering what to do during the initial stages of the Chavista regime, considered the issue of uncertainty. Regional institutions, although conscious about the populistic character of a regime, may be ignorant of what is going to happen in the future. There is a relevant probability that the regime will harass minority rights. Nonetheless, there is also a possibility that the regime, for different reasons, may act benignly to its citizens. In this context, and considering the potential costs associated with early scrutiny, regional institutions are likely to prefer a more deferential approach to supervision, at least during the first years of the populist regime.

This framework permits us to better understand why both the IACHR and the IACtHR adopted a deferential approach to Chávez during the first years of his regime. Both institutions assumed that stricter scrutiny on the regime would have induced Chávez to withdraw his consent to regional supervision. In turn, this decision would have likely led other states to react in the same way in a show of support for Venezuela. This represented an intolerable cost for regional institutions, whose jurisdiction had been under risk in such a context. Therefore, both the IACHR and the IACtHR decided to adopt a deferential policy to Chávez during the first years of his regime. By so doing, they sought to optimize, on the one side, the need to preserve their powers of supervision and, on the other side, the necessity to keep Venezuela under regional control.

Early decisions adopted by regional institutions when dealing with populism may produce impacts beyond what the institutions expected or desired. For instance, the strategy developed by both the IACHR and the IACtHR to supervise Chávez during the period between 1999 and 2002 had different side effects, some of which were more salutary than others.

First, by avoiding an initial condemnation for the regime, the IACHR not only prevented Venezuela from withdrawing its consent and averted a generalized backlash between States and the Commission. The IACHR's strategy also attracted Chávez's support for the system as a sort of side effect. Chávez's visit to the headquarters of the Commission in 1999 illustrates this achievement. Additionally, the Caracazo decision made by the IACtHR in 1999 reinforced Chávez's conviction to support regional supervision.

Second, another side effect regarded the position of Chávez himself. In effect, due to the deferential line of action developed by both the IACHR and the IACtHR between 1999 and 2002, the position of Chávez within and outside Venezuela became stronger. Chávez perceived regional

${ }^{77}$ I thank Professor Oran Doyle for making this valuable point. 
supervision as not harmful enough because both the IACHR and the IACtHR did not criticize him during those years. Additionally, what these institutions did at that time was perceived as politically beneficial by Chavez. This because the IACtHR condemned Venezuela due to measures adopted by administrations to which Chávez had been opposed in the past. In these two cases, regional supervision became very useful for Chávez during his early years in power. Because of the cautious attitude taken by both the IACHR and the IACtHR, these regional institutions contributed in part to an early legitimization of Chávez's position in front of the international community, and, vis-à-vis, his political opposition within Venezuela. Evidently, this approach contributed to fortify populist rule over the Venezuelans from 1999 to 2002. This happened even though regional institutions never intended such.

In conclusion, both the IACHR and the IACtHR, when dealing with the recently elected President Chávez, had strong reasons for adopting a more deferential approach in reviewing his populist policies.

\section{Remedying the evils: the friend and foe dynamics of populism}

As illustrated above, the deferential strategy deployed by both the IACHR and the IACtHR in checking the Chávez regime between 1999 and 2002 was due to constraints implicit in the normative framework of the Inter-American system of human rights protections. We now move on to considering the dynamics of regional supervision over Venezuela since Chávez consolidated his position of power within Venezuela in 2003.

Once Chávez defeated the 2002 coup d'état, his populist path to dictatorship became crystal clear to both the IACHR and the IACtHR. As discussed above, the IACHR responded by publishing a complete country report in 2003, denouncing the multiple human rights abuses committed by the regime. New reports were published in 2009 and 2017. Moreover, the IACtHR decided a series of cases condemning the Chavista regime since 2005. In other words: When human rights institutions of the Americas realized the populist and authoritarian purposes of the actions implemented by el Comandante Hugo Chávez in Venezuela, they increased their level of scrutiny on him.

Yet, despite all of the efforts deployed by both the IACHR and the IACtHR, this story did not have a happy ending. The regime, now under the authoritarian rule of Nicolás Maduro, never modified Chávez's policies, putting Venezuela at the edge of the abyss. Furthermore, Chávez announced in 2012 his decision to denunciate the American Convention on Human Rights. In sum, all attempts to restrain populist rule in Venezuela were ultimately impotent to end the abusive policies of the regime. This panorama is even more desolating when considering the fact that regional supervision over the Latin American region is much more limited today than in it was in 2003.

The question that emerges is why all efforts deployed by regional institutions since 2003 were unable to reshape the policies of the Chavista regime. A possible response to this inquiry has to do with an unexpected side effect produced by the intensification of regional supervision of Chávez after he gained full control over Venezuela.

Paradoxically, this intense supervision implemented by both the IACHR and the IACtHR to keep the solidly placed Chavista regime under control ultimately reinforced the populist rule in Venezuela. This undesired effect of regional supervision originated as a result of the perverse dynamics of populism. In effect, the criticism conducted by both the IACHR and the IACtHR allowed Chávez to deploy his populist strategy of friend and foe. By so doing, Chávez reinforced his rule over the country by galvanizing his supporters against a single enemy: Foreign institutions. In this scenario, both the IACHR and the IACtHR became an easy target for Chavistas, due to the issue of state consent.

In general terms, once regional institutions increase the intensity of supervision, the possibility is opened for populist authorities to react by initiating a political battle against those institutions. 
Because this battle will allow populists to reunite around a single leader to confront a new and common enemy, populism will possibly become stronger. This renewed strength may reinforce populist rule in the medium and long term.

Additionally, regional institutions, such as the IACHR and the IACtHR, represent an easy target for populisms. States have the key that opens the door to supervision. If states do not want to be supervised by foreign institutions, they can either refuse to give consent or withdraw its consent after being given. In these two scenarios, regional institutions become impotent to check populist authorities from abroad. This ends the game. From this perspective, populists may well consider regional institutions as easy targets to defeat. Furthermore, attacking regional institutions offers to populist rhetoric the opportunity to develop a nationalistic discourse, which is likely to be well received by the masses that are manipulated by such toxic forms of leadership. In this context, it is not rare for populists to actively engage in struggles against regional institutions. In effect, populist leaders see an opportunity to strengthen their rule when they are faced with an enemy that they will likely defeat after some struggle.

A final factor to consider is that meaningful reaction against regional institutions is likely to emerge when populist authorities have already secured their power over the nation. Campaigning against regional institutions is not cost free. In practice, populist leaders assume that this struggle will produce political costs for themselves, particularly in the short term. The international community is likely to isolate these leaders because of their virulent criticism against these human rights organizations. Additionally, this campaign is likely to encourage domestic opposition and demonstration of the regime's abuses. Because of these potential costs involved, populists react against regional supervision only after they have become stronger internally. By so doing, populist leaders reduce potential costs involved in attacking regional institutions. In turn, by reducing these costs, populists enjoy a greater chance of success. In this scenario, the benefits brought by conflict will exceed the political costs.

This explains why populists' first reaction against regional institutions can be timid. As they lack sufficient popular support, they prefer to wait. In this initial context, political costs that come from aggressive action against regional institutions are possibly too high for the populist to tolerate. Nonetheless, this sort of inaction does not represent a problem for the populist leader. Because regional institutions are likely to act in an extremely cautious manner toward populist authorities during the first stages of their regimes, there is no real incentive for these leaders to begin a battle against foreign supervision. Only later-when regional institutions start really playing their role of watchdogs-do populists have real incentives to struggle against them.

Consider what happens with regional human rights institutions when they start to seriously criticize populists who are in full control of the state apparatus. In this situation, populist leaders may respond to the criticism by challenging the legitimacy of the regional system. This can focus on the supranational bodies' lack of political impartiality, their sociological bias, or simply the cultural imperialism that supposedly exists behind them. Usually, this criticism is presented by an extremely virulent rhetoric against regional institutions. Populist leaders may also victimize themselves in front of their supporters, presenting a well-planned strategy developed from abroad whose only purpose is to destabilize the country. Moreover, populist leaders can appeal to the dignity of national sovereignty in very nationalistic terms.

The impact of these actions within the domestic sphere creates a sense of social struggle that is apt to mobilize populist majorities and unite themselves against the new enemy under one leadership. It is precisely this circumstance that makes populism stronger when reacting against international supervision. By adopting this strategy, populist leaders galvanize their supporters and demonstrate their own authority over the people. This allows populism to exhibit its powerful cohesiveness to both the international community and the domestic opposition. After this, populist rule within the country looks more consolidated than ever.

Sometimes, this strategy goes beyond the national sphere, expanding the struggle beyond national borders by forming alliances with other states party to the regional system. By so doing, 
the leader seeks to undermine either the legitimacy of the system, its workability, or both. Populist leaders may deploy this strategy when they perceive support from other states that follow the same political line. This can also evidence the populist's leadership in the region. In this respect, intense regional supervision not only contributes to making the position of the populist leader stronger within the country, but it also may contribute to: (a) Reinforcing the leadership of the populist ruler in the region; and (b) developing continental opposition to the system of regional supervision.

Another relevant factor that populists probably consider is how non-populist states are likely to respond to their move against the system of regional supervision. If the populist leader believes that his strategy of aggression will not cause other states to act individually or collectively against him, it is easier for him to decide to act against regional institutions. In this regard, lack of likely responses from non-populist states will likely exacerbate the situation.

This strategy of tension developed by the populist leader will likely end when the benefits reported to the ruler of sustaining this struggle are quickly decreasing. This may happen when the struggle has lost its novelty and the need to seek a different enemy is perceived as a priority. In this context, the inexistence of profits and the potential costs associated with inaction demands new enemies and new fights. This may also occur when the international strategy developed by the populists fails and states party to the system react in a way that unexpectedly increases the political costs to the populist leader. Finally, this situation may also take place when the conflict becomes irrelevant for regional institutions, which then discourages the populist regime from continuing in its action against the regional institutions.

In those cases, the conflict may finish when the populist leader abandons the struggle by performing a symbolic action that reaffirms his final victory. The populist leader simply withdraws the consent of the state authorizing further regional supervision, after convincing national majorities about how unjust and partial supranational organizations are. When this happens, the leader must then look for other conflicts to keep social tension in his favor.

This thesis may partially explain why the results of the efforts deployed by both the IACHR and the IACtHR against the Chávez regime were not those that the institutions expected. In effect, instead of preventing the regime from abusing human rights, supervision conducted by both the IACHR and the IACtHR encouraged populism to mobilize their supporters in favor of Hugo Chávez. In this regard, Chávez knew that by fighting those institutions, he was invigorating his internal front in Venezuela. Even more, in doing so, he also reinforced his role as a continental leader. In this respect, a well-intentioned strategy developed by Inter-American institutions of human rights became self-defeating.

The pattern of facts is similar to that described above. By initiating this fight against regional supervision, Chávez created a political conflict that permitted him to energize his supporters around his leadership. ${ }^{78}$ In fact, he presented himself to the people as someone who was fighting for the dignity of Venezuela abroad. In this struggle against regional institutions, Chávez employed an extremely virulent rhetoric. This allowed him to catch the attention of all Venezuelans, who received explanations in a language that, despite or because of its aggression, was clear and direct. Indeed, in a speech from February 2010, Chávez called the IACHR "ignominious," "disastrous," and "a true mafia." He also referred to Santiago Cantón, his former Executive Secretary, as "an Executive excrement, a pure one." Finally, he referred to the 2009 country report on Venezuela as "garbage."79 Furthermore, when Chávez denounced the American Convention on Human

\footnotetext{
${ }^{78}$ Ángel R. Oquendo, The Politicization of Human Rights Within the Inter-American System and Beyond, 50 N.Y.U. J. INT'L L. \& POL. 1, 2-5 (2017).

${ }^{79}$ Maye Primera, Chávez Ordena la Salida de Venezuela de la CIDH [Chávez Orders the Departure of Venezuela from the IACHR], EL PAís, Feb. 26, 2010, https://elpais.com/internacional/2010/02/26/actualidad/1267138801_850215.html.
} 
Rights in July 2012, he said that the IACtHR was "ineffable" and "unworthy of being a human rights tribunal." 80

By using these strong and even disrespectful statements, Chávez consciously contributed to creating the atmosphere of social tension required to mobilize his supporters around him. This made his position stronger within Venezuela. Additionally, Chávez began an intense international campaign supported by his continental allies: ALBA States-such as Ecuador, Bolivia, and Argentina. This campaign purported to deprive both the IACHR and the IACtHR from their authority and their funding. ${ }^{81}$ Because of that, the system almost collapsed in 2016 due to a lack of financial resources. In turn, this allowed Chávez to assume a new regional leadership.

Nonetheless, the struggle had to end. There were a series of country reports and court decisions made against Venezuela, which resonated even far away from the Latin American continent. In this context, political costs became more visible for Chávez both inside and outside the country. Consequently, the benefits of his policy of aggression against regional institutions began to decrease. Due to this, Chávez decided to finish the dispute with the IACHR and the IACtHR by finally denouncing the American Convention on Human Rights in 2012. Yet, the system is still supervising Venezuela by deciding cases presented to the system before 2012. This has allowed Nicolás Maduro, Chávez's successor, to repeat the strategy developed by el Comandante, following almost the same violent rhetoric employed by his predecessor. ${ }^{82}$

Chávez sought to escalate the conflict against regional institutions not only defend him from the multiple accusations made by both the IACHR and the IACtHR, but also to capitalize on an opportunity to reinforce his leadership within Venezuela and the surrounding region. This situation represents a true paradox. Tragically, by increasing their level of supervision, both the IACHR and the IACtHR contributed to reinforcing Chávez's rule in Venezuela. Of course, this does not mean that regional institutions of the Inter-American system pursued this objective. On the contrary, with more or less intensity, both the IACHR and the IACtHR always confronted the Chavista regime with the sole purpose of stopping human rights abuses in Bolívar's motherland. In so doing, these institutions assumed, and continue to assume, many political and financial costs.

The reason why increased supervision from abroad unexpectedly reinforced the rule of Chávez over Venezuela had to do with the internal — and perverse-dynamics of populism. Because populist regimes survive thanks to political and social conflicts animated by their leaders, regional supervision encouraged Chávez not to change his own dictatorial path. On the contrary, criticisms led him to massively confront both the IACHR and the IACtHR. Keeping this conflict alive permitted Chávez to solidify his position in Venezuela. This was because the political benefits perceived by el Comandante were far more than the costs he had to assume. Later, when Chávez exhausted all benefits derived from this conflict, he exited the system to prevent the potential costs that would likely come in the short term.

\footnotetext{
${ }^{80}$ Venezuela se $\mathrm{Va}$ de la Corte Interamericana de Derechos Humanos [Venezuela Leaves the Inter-American Court of Human Rights], ClaRín, July 27, 2012, https://www.clarin.com/mundo/venezuela-corte-interamericana-derechos-humanos_ $0 \_$SyYHLtW3Dmx.html.

${ }^{81}$ James Cavallaro, Al Borde del Abismo: La Comisión Interamericana de Derechos Humanos Enfrenta la Peor Crisis Financiera de la Historia [On the Edge of the Abyss: The Inter-American Commission on Human Rights Faces the Worst Financial Crisis in History], EL PAís, (May 23, 2016, 11:25 AM), https://elpais.com/internacional/2016/05/23/america/ 1464011720_921111.html; see also Press Release No. 69, Inter-Am. Comm'n H.R. (May 23, 2016), http://www.oas.org/en/ iachr/media_center/PReleases/2016/069.asp.

${ }^{82}$ Maduro rechaza declaraciones de la "cuestionada" CIDH sobre Venezuela [Maduro Rejects Statements of the "Questioned" IACHR on Venezuela], El NuEvo DiARIO, (May 10, 2013, 2:19 PM), https://www.elnuevodiario.com.ni/internacionales/ 285683-maduro-rechaza-declaraciones-cuestionada-cidh-vene/. For a reaction against the position of Maduro, see Cristopher Sabatini \& Jimena Galindo, It's Not Just Venezuela: Elected Governments Don't Necessarily Defend Democracy or Protect Human Rights, WASH. Post, Aug. 11, 2017, https:/www.washingtonpost.com/news/monkey-cage/wp/2017/08/11/its-notjust-venezuela-elected-governments-do-not-necessarily-defend-democracy-or-protect-human-rights/?utm_term=.f795c7e3b775.
} 


\section{E. Conclusion}

Latin American history is rich in examples of populisms. The latest populist wave included what is dubbed neo-populisms. The main representative of neo-populism is the Chavista regime of Venezuela, conducted first by Hugo Chávez and today by Nicolás Maduro.

International human rights law expects that regional institutions will either prevent or stop abuses committed by populist regimes. Yet, this general assumption is not always correct, as the experience of Venezuela demonstrates. This Article illustrates how the attempts of both the IACHR and the IACtHR to intervene and struggle against the abuses of the Chavista regime became ineffective, or even self-defeating.

This is not intended as a criticism of the IACHR and the IACtHR. On the contrary, these institutions have given voice to many victims oppressed by the populist rule of Chávez and Maduro. Additionally, decisions made by both the IACHR and the IACtHR influenced further actions taken by regional organs, such as the OAS. Nonetheless, the Venezuelan experience teaches that the action of regional human rights institutions, while significant, sometimes is insufficient in either preventing or stopping a populist regime from abusing political minorities.

Cite this article: Candia G (2019). Regional human rights institutions struggling against populism: The case of Venezuela. German Law Journal 20, 141-160. https://doi.org/10.1017/glj.2019.10 